\title{
PERAN GURU DALAM PELAKSANAAN PENDIDIKAN KARAKTER PADA SISWA KELAS X DI SEKOLAH MENENGAH ATAS NEGERI 1 PALANGKA RAYA
}

\author{
Dewanto Zulkarnain \\ STMIK Palangka Raya \\ Email : dewa.congo64@gmail.com
}

\begin{abstract}
ABSTRAK
Penelitian ini dilatar belakangi karena pembentukan karakter khususnya pada siswa kelas X Sekolah Menengah Atas Negeri 1 Palangka Raya masih belum dilaksanakan guru dengan tepat. Metode yang digunakan dalam penelitian ini adalah metode deskriptif dalam bentuk studi survei. Berdasarkan hasil penelitian peran guru dalam pelaksanaan pendidikan karakter pada siswa kelas $\mathrm{X}$ di Sekolah Menengah Atas Negeri 1 Palangka Raya, guru masih lebih mengedepankan pencapaian prestasi akademis setinggi-tingginya tanpa memperhatikan yang lain seperti pembentukan karakter para siswa-siswanya terlebih di kelas X. Karakter seorang guru seharusnya bisa menjadi teladan bagi para siswa-siswanya.
\end{abstract}

\section{Kata Kunci : Peran Guru, dan Pendidikan Karakter}

\section{PENDAHULUAN}

Guru merupakan sosok yang menjadi idola bagi anak didik keberadaannya sebagai jantung pendidikan tidak bisa dipungkiri. Baik atau buruknya pendidikan sangat tergantung pada guru. Untuk melaksanakan fungsi dan peranan dalam proses belajar mengajar, guru sebagai jabatan profesi dituntut memiliki keahlian agar dapat melaksanakan tugasnya sebagai pendidik dan pengajar dalam membentuk perilaku siswa sesuai dengan kualitas manusia Indonesia yang dicitacitakan sebagaimana yang dikehendaki dalam Undang-Undang Sistem Pendidikan Nasional No. 20 Tahun 2003 Bab III Pasal 3 menyatakan bahwa: Pendidikan nasional berfungsi mengembangkan kemampuan dan membentuk watak serta peradapan bangsa yang bermartabat dalam rangka mencerdaskan kehidupan bangsa, bertujuan untuk mengembangkannya potensi peserta didik agar menjadi manusia yang beriman kepada Tuhan Yang Maha Esa, berakhlak mulia, berakal sehat, berilmu, cakap, kreatif, mandiri dan menjadi warga negara yang demokratis serta bertanggung jawab.
Dalam pendidikan karakter, peran guru sangat vital sebagi sosok yang diidolakan, serta sumber inspirator dan motivasi murid-muridnya. Sikap dan prilaku seorang guru sangat membekas dalam diri seorang murid, sehingga ucapan, karakter dan kepribadian guru menjadi cermin murid. Menurut Nur Arifah (dalam Jamal Ma'mur, 2011:74) mengatakan: "Guru dan pendidik memiliki tanggung jawab besar dalam menghasilkan generasi yang berkarakter, berbudaya, dan bermoral. Guru merupakan teladan bagi siswa dalam memiliki peran yang sangat besar dalam pembentukan karakter siswa".

Pendidikan karakter adalah segala sesuatu yang dilakukan oleh guru untuk mempengaruhi karakter peserta didik. Guru membantu dalam watak peserta didik dengan cara memberikan keteladanan, cara berbicara atau menyampaikan materi yang baik, toleransi, dan berbagai hal yang terkait dengannya. Mengingat pentingnya karakter dalam membangun sumber daya manusia (SDM) yang kuat, maka perlunya pendidikan karakter yang dilakukan dengan tepat. Dapat 
dikatakan bahwa pembentukan karakter merupakan sesuatu yang tidak dapat dipisahkan dari kehidupan. Oleh karena itu, pendidikan karakter harus menyertai semua aspek kehidupan termasuk di lembanga pendidikan. Idealnya pembentukan atau pendidikan karakter diintegrasikan ke seluruh aspek kehidupan sekolah.

Penelitian ini berusaha menunjukan usaha praktis yang dapat dilakukan para guru dalam membangun karakter siswa. Dengan adanya penelitian ini diharapkan siswa mampu secara mandiri meningkatkan dan menggunakan pengetahuannya, mengkaji dan menginternalisasi serta mempersonalisasi nilai-nilai karakter dan akhlak mulia serta membentuk karakter siswa sesuai dengan moral Pancasila sehingga terwujud dalam perilaku sehari-hari dan dapat membangun sumber daya manusia (SDM) yang kuat.

Berdasarkan hasil pra survey yang penulis, diperoleh informasi bahwa pembentukan karakter khususnya pada siswa kelas $\mathrm{X}$ belum dilaksanakan guru dengan tepat. Para guru lebih mengedepankan pencapaian prestasi akademis setinggitingginya tanpa memperhatikan yang lain seperti pembentukan karakter. Hal ini disebabkan karena banyak guru yang kurang memahami posisi dalam pembentukan karakter siswa, sehingga dapat mempengaruhi tingkah laku siswa dalam belajar. Dengan demikian dapat diasumsikan bahwa pembentukan karakter siswa tidak terlepas dari kemampuan guru menumbuhkan semangat dan menanamkan kepercayaan kepada diri siswa untuk menjadi dasar bagi perkembangan atau pembinaan moral sehingga siswa dapat memilih mana yang baik untuk mereka.

Realitas inilah yang mendorong peneliti untuk mengangkat masalah ini lebih lanjut dalam bentuk penelitian yaitu: "Peran Guru Dalam Pelaksanaan Pendididikan Karakter Pada Siswa Kelas X Di Sekolah Menengah Atas Negeri 1 Palangka Raya”.

\section{KAJIAN TEORI Pengertian Peran Guru}

Peran guru sangat vital sebagi sosok yang diidolakan dalam proses pembelajaran, serta menjadi sumber inspiratorsi dan motivasi murid-muridnya. Sikap dan prilaku seorang guru sangat membekas dalam diri seorang murid, sehingga ucapan, kepribadian guru menjadi cermin murid. Menurut Djamarah, S.B (2005:32) : "Guru adalah semua orang yang berwenang dan bertanggung jawab untuk membimbing dan membina anak didik, baik secara individual maupun klasikal, di sekolah maupun di luar sekolah". Guru atau pendidik memiliki tanggung jawab besar dalam menghasilkan generasi yang berkarakter, berbudaya, dan bermoral.

\section{Komitmen Guru dalam Pelaksanaan Pendidikan Karakter}

Komitmen harus dilakukan oleh seorang guru. Guru yang memiliki komitmen yang kuat ia juga memiliki visi ke depan dalam rangka mewujudkan tujuan pendidikan karakter di sekolah. Komitmen merupakan ucapan yang mengikat seseorang untuk melakukan sesuatu. Dengan demikian, komitmen guru dapat didefinisikan sebagai suatu tekad yang mengikat seorang guru untuk melakukan tugas dan tanggung jawabnya sebagai pendidik. (Novan A.W, 2012:89).

\section{Bentuk-Bentuk Peran Guru}

Banyak peranan yang diperlukan dari guru sebagai pendidik, atau siapa saja yang telah menerjunkan diri menjadi guru. Semua peranan yang diharapkan dari guru seperti 1) Keteladanan, guru sebagai seorang teladan harus berhati-hati dalam penampilannya dimana guru harus terlepas dari kesalahankesalahan sehingga siswa-siswanya tidak akan meniru tingkah laku yang salah; 2) Inspirator, guru harus dapat memberikan petunjuk (ilham) bagaimana cara belajar yang baik. 3) Motivator, guru harus dapat merangsang dan memberikan dorongan serta reinforcement untuk mendinamisasikan potensi siswa, 
menumbuhkan swadaya (aktivitas) dan daya cipta (kreativitas), sehingga akan terjadi dinamika di dalam proses belajar mengajar; 4) Dinamisator artinya, seorang guru yang tidak hanya membangkitkan semangat, tetapi juga menjadi lokomotif yang benar-benar mendorong kearah tujuan dengan kecepatan, kecerdasan, kearifan yang tinggi; 5) Evaluator,guru harus mampu mengevaluasi sikap perilaku yang ditampilkan, sepak terjang dan perjuangan yang digariskan, dan agenda yang direncanakan.

\section{Teknik yang Digunakan Guru Dalam Pelaksanaan Pendidikan Karakter}

Mencapai tujuan peningkatan karakter siswa bisa jadi merupakan tugas terberat bagi para guru. Perhatian dan tanggung jawab tidak dapat dimunculkan begitu saja dalam satu kali pelajaran. Frustasi akan dialami beberapa guru, namun bagi guru yang berhasil membangun karakter siswa dengan berbagai cara akan memperoleh kepuasan yang luar biasa.

\section{Pendidikan Karakter}

Karakter, gabungan dari kebijakan dan nilai-nilai yang dipahat di dalam batu hidup tersebut, akan menyatakan nilai yang sebenarnya. Tidak ada perbaikan yang bersifat kosmetik, tidak ada suasana dekorasi yang dapat membuat batu yang tidak berguna menjadi suatu seni yang bertahan lama. Hanya karakter yang dapat melakukannya. Rutland (2009:1) mengemukakan bahwa : "Karakter berasal dari akar kata bahasa Latin yang berarti "dipahami". Sedangkan Baharuddin (2007:193) : "Karakter diartikan sebagai suatu keadaan jiwa yang tampak dalam tingkah laku dan perbuatan sebagai akibat pengaruh pembawaan dan lingkungan". Pendidikan karakter dapat dimaknai dengan pendidikan nilai, pendidikan budi pekerti, pendidikan moral, pendidikan watak yang bertujuan untuk memberikan keputusan baik-buruk memelihara apa yang baik, dan mewujudkan kebaikan itu dalam kehidupan sehari-hari dengan sepenuh hati. Pendidikan karakter dapat dimaknai sebagai sistem penanaman nilai-nilai karakter kepada warga sekolah yang meliputi komponen pengetahuan, kesadaran atau kemauan dan tindakan untuk melaksanakan nilai-nilai tersebut, baik terhadap Tuhan Yang Maha Esa, diri sendiri, sesama, lingkungan, maupun kebangsaan sehingga menjadi insan kamil. Demikian juga, seseorang pendidik dikatakan berkarakter jika ia memiliki nilai dan keyakinan yang dilandasi hakikat dan tujuan pendidikan serta digunakan sebagai kekuatan moral dalam menjalakan tugasnya sebagai pendidik. Pendidikan karakter sering juga disebut dengan pendidikan nilai karena karakter adalah value in action nilai yang diwujudkan dalam tindakan. Karakter juga serinag disebut operative value atau nilai-nilai yang dioperasionalkan dalam tindakan (perilaku). Oleh karena itu, pendidikan karater merupakan upaya menginternalisasikan, menghadirkan, menyemaikan dan mengembangkan nilai-nilai kebaikan pada diri peserta didik. Dengan internalisasi nilai-nilai kebajikan tersebut, diharapkan dapat mewujudkan peserta didik berperilaku baik.

\section{Metode dan Bentuk Penelitian}

Metode dalam penelitian ini adalah metode deskriptif. Sehubungan dengan itu John W. Best (dalam Baeley, D.K. 1982:116 ) mengatakan: "A descriptive study disrobes and interprets what is, opinious that a held processed that are going on, effect are evident or trend that are developin". Artinya: penelitian deskriptif menggambarkan dan menginterprestasikan apa adanya. Penelitian deksriptif berkenaan dengan kondisi atau hubungan-hubungan yang ada, pendapatpendapat yang disampaikan, proses-proses yang berlangsung, pengaruh-pengaruh yang berupa bukti-bukti atau kecendrungankecenderungan yang berkembang".

Penelitian yang sesuai dengan masalah dan tujuan penelitian ini adalah studi survei (Survey Study). Pemilihan bentuk ini disebabkan penelitian ini bertujuan untuk mengetahui sejauh mana peran guru dalam 
pelaksanaan pendidikan karakter khususnya bagi para siswa kelas X Sekolah Menengah Atas Negeri 1 Palangka Raya. Menurut Riduwan (2004:49) metode penelitian dapat berbentuk: "Metode penelitian survey, ex post facto, eksperimen, naturalistic, policy research (penelitian policy), action research (penelitian tindakan).

\section{HASIL DAN PEMBAHASAN}

Langkah-langkah menentukan tolok ukur penilaian peran guru dalam pelaksanaan pendidikan karakter pada siswa kelas $\mathrm{X}$ Sekolah Menengah Atas Negeri 1 Palangka Raya menggunakan pendapat Suharsimi Arikunto (2005:236) yaitu :

1. Mencari skor maksimal ideal yaitu jumlah sampel $\mathrm{x}$ skor tertinggi suatu item : $75 \times 4=$ 300

2. Mencari rata-rata ideal yaitu skor maksimal ideal dibagi $2: 300: 2=150$

3. Mencari standar deviasi ideal yaitu rata-rata ideal dibagi $4: 150: 4=37,5$

4. Mencari nilai $Z$ untuk daerah 34,14 =1,00.

5. Mencari $\bar{X}$ ideal - $(Z \times x$ Sideal $)$ sampai dengan $\overline{\mathrm{X}}$ ideal $+(\mathrm{Z} \times \mathrm{S}$ ideal $)$ :

$=150-(1,00 \times 37,5)$ sampai dengan $150+$ $(1,00 \times 37,5)$
6. Untuk kategori "sangat baik" adalah di atas rentang skor "baik" yaitu 187,50 sampai 300 .

7. Untuk kategori "cukup baik" adalah dibawah rentang skor "baik" yaitu 37,50 sampai 112,50 .

8. Untuk kategori "kurang baik" adalah di atas rentang skor "cukup baik" yaitu 0 sampai dengan 37,49.

Berdasarkan perhitungan ini maka tolak ukur katagori penilaian yang digunakan berdasar tabel dibawah:

\begin{tabular}{|c|l|c|c|}
\hline No & \multicolumn{1}{|c|}{$\begin{array}{c}\text { Kategori } \\
\text { Penilaian }\end{array}$} & Skor & Persentase \\
\hline 1. & $\begin{array}{l}\text { Sangat } \\
\text { Tinggi/Sangat }\end{array}$ & $\begin{array}{c}187,50 \\
-\end{array}$ & $\begin{array}{c}66,67 \%- \\
100 \%\end{array}$ \\
& Baik & 252,00 & \\
\hline 2. & Tinggi/Baik & 112,50 & $33,33 \%-$ \\
& & - & $66,66 \%$ \\
& & 187,49 & \\
\hline 3. & Cukup & $37,50-$ & $16,67 \%-$ \\
& & 112,49 & $33,32 \%$ \\
\hline 4. & Kurang & $00,00-$ & $00,00 \%-$ \\
& Baik/Rendah & 37,49 & $16,66 \%$ \\
\hline
\end{tabular}

Berdasarkan aspek-aspek peran guru dalam pelaksanaan pendidikan karakter pada siswa kelas X Sekolah Menengah Atas Negeri 1 Palangka Raya dapat dikategorikan sebagai berikut.

\begin{tabular}{|c|l|c|c|c|c|}
\hline No & \multicolumn{1}{|c|}{ Aspek Variabel } & $\begin{array}{c}\text { Skor } \\
\text { Aktual }\end{array}$ & $\begin{array}{c}\text { Skor } \\
\text { Maks } \\
\text { Ideal }\end{array}$ & $\mathbf{\%}$ & $\begin{array}{c}\text { Kategori } \\
\text { Penilaia } \\
\text { n }\end{array}$ \\
\hline A. & $\begin{array}{l}\text { Komitmen Guru Dalam } \\
\text { Pelaksanaan Pendidikan Karakter }\end{array}$ & $\mathbf{2 0 1 2}$ & $\mathbf{2 4 0 0}$ & $\mathbf{8 3 , 8 3}$ & $\begin{array}{c}\text { Sangat } \\
\text { Baik }\end{array}$ \\
\cline { 2 - 6 } & $\begin{array}{l}\text { Melaksanakan sosialisasi } \\
\text { pendidikan karakter dan } \\
\text { melakukan komitmen bersama } \\
\text { antara seluruh komponen warga } \\
\text { sekolah }\end{array}$ & 523 & 600 & 87,17 & $\begin{array}{c}\text { Sangat } \\
\text { Baik }\end{array}$ \\
$\begin{array}{l}\text { Membuat komitmen dengan } \\
\text { semua stakeholder untuk } \\
\text { mendukung pelaksanaan } \\
\text { pendidikan karakter }\end{array}$ & 484 & 600 & 80,67 & $\begin{array}{c}\text { Sangat } \\
\text { Baik }\end{array}$ \\
\cline { 2 - 6 } & $\begin{array}{l}\text { Membuat perencanaan dan } \\
\text { program pelaksanaan pendidikan } \\
\text { karakter }\end{array}$ & 514 & 600 & 85,67 & $\begin{array}{c}\text { Sangat } \\
\text { Baik }\end{array}$ \\
\cline { 2 - 6 } & Melakukan pengondisian & 491 & 600 & 81,83 & $\begin{array}{c}\text { Sangat } \\
\text { Baik }\end{array}$ \\
\hline
\end{tabular}


Jurnal Civic Education, Vol. 3 No. 1 Juni 2019

\begin{tabular}{|c|c|c|c|c|c|}
\hline \multirow[t]{6}{*}{ B. } & $\begin{array}{l}\text { Bentuk-Bentuk Peran Guru } \\
\text { Dalam Pelaksanaan Pendidikan } \\
\text { Karakter }\end{array}$ & 2449 & 3000 & 81,63 & $\begin{array}{c}\text { Sangat } \\
\text { Baik }\end{array}$ \\
\hline & Keteladanan & 493 & 600 & 82,17 & $\begin{array}{l}\text { Sangat } \\
\text { Baik }\end{array}$ \\
\hline & Inspirator & 483 & 600 & 80,50 & $\begin{array}{l}\text { Sangat } \\
\text { Baik }\end{array}$ \\
\hline & Motivator & 484 & 600 & 80,67 & $\begin{array}{l}\text { Sangat } \\
\text { Baik }\end{array}$ \\
\hline & Dinamisator & 498 & 600 & 83,00 & $\begin{array}{l}\text { Sangat } \\
\text { Baik }\end{array}$ \\
\hline & Evaluator & 491 & 600 & 81,83 & $\begin{array}{l}\text { Sangat } \\
\text { Baik }\end{array}$ \\
\hline \multirow[t]{3}{*}{ C. } & $\begin{array}{l}\text { Teknik yang Digunakan Guru } \\
\text { Dalam Pelaksanaan Pendidikan } \\
\text { Karakter }\end{array}$ & 3103 & 3600 & 86,19 & $\begin{array}{c}\text { Sangat } \\
\text { Baik }\end{array}$ \\
\hline & $\begin{array}{l}\text { Membantu siswa agar saling } \\
\text { kenal }\end{array}$ & 517 & 600 & 86,17 & $\begin{array}{l}\text { Sangat } \\
\text { Baik }\end{array}$ \\
\hline & $\begin{array}{l}\text { Berperilaku sesuai dengan apa } \\
\text { yang ingin dilihat }\end{array}$ & 536 & 600 & 89,33 & $\begin{array}{l}\text { Sangat } \\
\text { Baik }\end{array}$ \\
\hline
\end{tabular}

\section{Komitmen Guru Dalam Pelaksanaan Pendidikan Karakter}

Seorang guru harus memiliki komitmen yang tinggi dalam melaksanakan tugasnya. Tanpa komitmen yang kuat, suatu tujuan tidak akan tercapai secara optimal bahkan dapat menuai suatu kegagalan. Sebaliknya, jika seorang guru tidak memiliki komitmen yang kuat berarti ia tidak amanah dan bahkan mengabaikannya. Orang yang mengabaikan amanah akan berakibat bukan hanya kegagalan bahkan kehancuran.

Dengan demikian, komitmen merupakan langkah awal dalam menerima, mematuhi, dan mengemban amanah. Perwujudan komitmen guru dalam pelaksanaan pendidikan karakter disekolah menurut Novan A.W (2012:89) antara lain:

a. Melaksanakan sosialisasi pendidikan karakter dan melakukan komitmen bersama antara seluruh komponen warga sekolah (tenaga pendidik dan kependidikan serta komite sekolah)

b. Membuat komitmen dengan semua stakeholder (seluruh warga sekolah, orang tua siswa, komite dan tokoh masyarakat setempat) untuk mendukung pelaksanaan pendidikan karakter

c. Melakukan analisis konteks terhadap kondisi sekolah (internal dan eksternal) yang dikaitkan dengan nilai-nilai karakter yang akan dikembangkan pada satuan pendidikan yang bersangkutan. Analisis ini dilakukan untuk menetapkan nilai-nilai dan indikator keberhasilan yang diprioritaskan, sumber daya, sarana yang diperlukan, serta prosedur penilaian keberhasilan

d. Menyusun rencana aksi sekolah berkaitan dengan penetapan nilai-nilai pendidikan karakter

e. Membuat perencanaan dan program pelaksanaan pendidikan karakter, yang berisi:

1) Pengintegrasian melalui pembelajaran

2) Penyusunan mata pelajaran muatan lokal

3) Penjadwalan dan penambahan jam belajar di sekolah

f. Melakukan pengondisian, seperti:

1) Penyediaan sarana

2) Keteladanan

3) Penghargaan dan pemberdayaan

Untuk keberlangsungan pelaksanaan pendidikan karakter, perlu dilakukan penilaian keberhasilan dengan menggunakan 
indikator-indikator berupa perilaku semua warga dan kondisi sekolah. Penilaian dilakukan secara terus menerus melalui berbagai strategi. Supervisi dilakukan mulai dari menelaah kembali perencanaan, kurikulum, dan pelaksanaan semua kegiatan yang berkaitan dengan pendidikan karakter, yaitu:

a. Implementasi program pengambangan diri berkaitan dengan pengembangan nilai pendidikan budaya dan karakter bangsa dalam budaya sekolah

b. Kelengkapan sarana dan prasarana pendukung implementasi pengembangan nilai pendidikan budaya dan karakter bangsa

c. Implementasi nilai dalam pembelajaran

d. Implementasi belajar aktif dalam pembelajaran

e. Ketercapaian Rencana Aksi Sekolah berkaitan dengan penerapan nilai-nilai pendidikan budaya dan karakter bangsa

f. Penilaian penerapan nilai pendidikan karakter dan budaya bangsa pada pendidik, tenaga kependidikan dan peserta didik (sebagai kondisi akhir)

g. Membandingkan kondisi awal dengan kondisi akhir dan merancang program lanjutan. (Novan A.W, 2012:90-91)

\section{Bentuk-Bentuk Peran Guru Dalam Pelaksanaan Pendidikan Karakter}

Banyak peranan yang diperlukan dari guru sebagai pendidik, atau siapa saja yang telah menerjunkan diri menjadi guru. Semua peranan yang diharapkan dari guru seperti diuraikan di bawah ini :

1. Keteladanan

Keteladanan merupakan hal mutlak yang harus dimiliki oleh guru. Dalam pendidikan karakter, keteladanan yang dibutuhkan oleh guru berupa konsistensi dalam menjalankan perintah agama dan menjauhi

larangan-larangannya.

Keteladanan guru sangat penting demi efekitifitas pendidikan karakter. Jamal Ma'mur A. (2011:75) mengatakan : “Tanpa keteladanan, pendidikan karakter kehilangan ruhnya yang paling esensial, hanya slogan, kamuflase, fatamorgana dan kata-kata negatif lainnya".

Menurut Monalisa Arbetina (2008:18) mengatakan bahwa: "Modeling can serve as a shortcut to learning, the teacher serving as a model must be careful that his performance is free of errors so that his students do not pick up incorrect behaviour". Artinya keteladanan mampu membantu proses pembelajaran dengan cepat, guru sebagai seorang teladan harus berhati-hati dalam penampilannya dimana guru harus terlepas dari kesalahan-kesalahan sehingga siswa-siswanya tidak akan meniru tingkah laku yang salah.

Di sinilah pentinya seluruh guru di negara ini merenungkan kembali peran dan fungsi utama mereka bagi pengembangan moral dan intelektual. Sudah waktunya mereka menjadi teladan utama dalam aspek pengetahuan, moral, dan perjuangan sosial demi bangkitnya negeri ini dari ketepurukan moral. Kedekatan peran guru dengan Tuhan dan kepedulian besar mereka terhadap sesama mutlak harus ditingkatkan sebagai basis keteladanan yang hakiki, yang tidak selalu berkaitan dengan kebutuhan material pragamatis.

2. Inspirator

Seseorang akan menjadi sosok inspirator jika ia mampu mengembangkan semangat untuk maju dengan menggerakan segala potensi yang dimiliki untuk meraih prestasi spektakuler bagi diri dan masyarakat. Menurut Zuldafrial (2011:271) mengatakan bahwa: "Sebagai inspirator, guru harus mampu memerankan diri dan memberikan inspirasi bagi siswa, sehingga kegiatan belajar dan pembelajaran dapat membangkitkan berbagai pemikiran, gagasan dan ide-ide baru". Persoalan belajar adalah masalah utama anak didik. Jika semua guru mampu menjadi sosok inspirator maka kader-kader bangsa akan muncul sebagai sosok inspirator. Di sinilah, sosok inspirator untuk mengobarkan semangat berprestasi di seluruh penjuru negeri ini, 
mereka mencurahkan segala daya dan upaya untuk meraih prestasi, membangun perbedaan, dan menjulangkan mimpi ke luar angkasa.

\section{Motivator}

Menurut Sardiman AM (2008:145) mengungkapkan : "Peranan guru sebagai motivator ini penting artinya dalam rangka meningkatkan kegairahan dan pengembangan kegiatan belajar siswa". Guru harus dapat merangsang dan memberikan dorongan serta reinforcement untuk mendinamisasikan potensi siswa, menumbuhkan swadaya (aktivitas) dan daya cipta (kreativitas), sehingga akan terjadi dinamika di dalam proses belajar mengajar. Penganekaragaman cara belajar memberikan penguatan juga dapat memberikan motivasi pada anak didik untuk lebih bergairah dalam belajar.

Dalam upaya memberikan motivasi, guru dapat menganalisis motif-motif yang melatarbelakangi anak didik malas belajar dan menurun prestasinya di sekolah. Motivasi dapat efektif bila dilakukan dengan memperhatikan kebutuhan anak didik. Peranan guru sebagai motivator ini sangat penting dalam interaksi belajar mengajar, karena menyangkut esensi pekerjaan mendidik yang membutuhkan kemahiran sosial, menyangkut performence dalam arti personalisasi dan sosialisasi diri.

\section{Dinamisator}

Peran guru sebagai dinamisator adalah guru yang tidak hanya membangkitkan semangat, tetapi juga mendorong siswa kearah tujuan dengan kecepatan, kecerdasan, kearifan yang tinggi sehingga dapat tercapai tujuan pembelajaran yang efektif dan efisien.

Seorang guru yang tidak hanya membangkitkan semangat, tetapi juga menjadi lokomotif yang benar-benar mendorong kearah tujuan dengan kecepatan, kecerdasan, kearifan yang tinggi. Berikut ini adalah krietria guru yang dinamisator menurut Jamal Ma'mur A. (2011:80) : a. Kaya gagasan dan pemikiran, serta mempunyai visi yang jauh ke depan.

b. Mempunyai kemampuan manajemen terstruktur, sistematis, fungsional, dan professional.

c. Mempunyai jaringan yang luas sehingga bisa melangkah secara ekspansif dan eksploratif.

d. Mempunayai kemampuan sosial dan humaniora yang bagus, sebab pendekatan persuasive-humanis emosional lebih efektif dalam memecahkan kebutuhan daripada sekedar formalis-organisatorislegalis.

e. Mempunyai kreativitas yang tinggi, khususnya dalam menciptakan dan mencari solusi daripada problem yang ada.

f. Mempunyai kematangan dalam berpolitik, antara fungsi stabilator dan dinamisator, di satu sisi menjaga stabilitas (keseimbangan), namun di sisi lain harus menggerakan progresi (kemajuan).

g. Harus mengedepankan kaderisasi dan regenerasi.

\section{Evaluator}

Sebagai evaluator, guru tidak hanya menilai produk (hasil pengajaran), tetapi juga menilai proses (jalannya pengajaran). Dari kedua kegiatan ini akan mendapatkan umpan balik (feedback) tentang pelaksanaan interaksi edukatif yang telah dilakukan.

Peran yang melengkapi peran-peran sebelumya adalah sebagai evaluator. Menurut Sardiman AM (2008:146) mengatakan bahwa: "Peran guru sebagai evaluator, guru mempunyai otoritas untuk menilai prestasi anak didik dalam bidang akademis maupun tingkah laku sosialnya, sehingga dapat menetukan bagaimana anak didiknya berhasil atau tidak". Ada kecendrungan bahwa peran sebagai evaluator, guru mempunyai otoritas untuk menilai prestasi anak didik dalam bidang akademis maupun tingkah laku sosialnya, 
sehingga dapat menentukan bagaimana anak didiknya berhasil atau tidak.

Tetapi kalau diamati secara agak mendalam evaluasi-evaluasi yang dilakukan guru itu sering hanya merupakan evaluasi ekstrinsik dan sama sekali belum menyentuh evaluasi yang intrinsik. Penilaian terhadap aspek intrinsik lebih menyentuh pada aspek kepribadian anak didik, yakni aspek nilai (values). Berdasarkan hal ini, guru harus bisa memberikan penilaian dalam dimensi yang luas. Penilaian terhadap kepribadian anak didik tentu lebih diutamakan daripada penilaian terhadapa jawaban anak didik ketika diberikan tes. Anak didikyang berprestasi baik, belum tentu memiliki kepribadian yang baik. Jadi, penilaian itu pada hakikatnya diarahkan pada perubahan kepribadian anak didik agar menjadi manusia susila yang cakap.

\section{Teknik yang Digunakan Guru Dalam Pelaksanaan Pendidikan Karakter}

Siswa-siswa yang karakternya sudah terbangun, diharapkan dimasa depan dapat memberikan perubahan ke arah positif bagi bangsa ini. Perubahan ini berada pada tangan para guru yang ada saat ini. Teknik yang digunakan guru dalam pelaksanaan pendidikan karakter yang akan dibahas meliputi:

a. Membantu siswa agar saling kenal

Banyak guru yang sudah memahami pentingnya mereka mengenal murid mereka, tapi hanya sedikit guru yang paham pentingnya siswa mereka mengenal satu sama lain. Menurut Sofan Amri, dkk (2011:98) mengatakan: "Dengan mengenal semua teman sekelasnya diharapkan dapat meningkatkan perhatian dan penghargaan terhadap teman-temannya". Hal ini juga ditujukan untuk menumbuhkan perasaan satu tim. Djamarah, S.B dan Aswan Zain (2010:88) mengatakan bahwa: "Untuk memperkenalkan siswa satu sama lain dapat dilakukan dengan merubah susunan duduk siswa secara periodik". Selain itu dengan merubah susunan duduk siswa secara periodik sehingga seorang siswa akan memiliki teman sebangku yang berbedabeda. Dengan melakukan hal ini siswa bisa lebih mengenal siswa lainnya.

b. Berperilaku sesuai dengan apa yang dilihat

Guru adalah model bagi muridnya, baik disadari ataupun tidak, siswa akan berperilaku mirip dengan gurunya (Bacon dalam Sofan Amri, 2011:99). Sedangkan menurut Djamarah, S.B dan Aswan Zain (2010:89) mengatakan: "Jika kita ingin para murid memiliki perilaku tertentu, kita harus memiliki perilaku tersebut terlebih dahulu". Mengucapkan terima kasih, tolong, meminta maaf, tidak memotong siswa yang mengutarakan pendapat, menghormati siswa merupakan strategi yang baik dalam character building.

c. Mengurangi tingkat frustasi

Siswa yang tidak dapat mengerjakan suatu pekerjaan biasanya akan memiliki perilaku yang buruk (Bacon dalam Sofan Amri, 2011:99). Sedangkan menurut Djamarah, S.B dan Aswan Zain (2010:89) mengatakan bahwa: "Tingkat frustasi siswa yang tinggi menjadi pengaruh utama munculnya perilaku-perilaku negatif pada siswa". Guru harus biasa memperkirakan tingkat kesulitan materi yang diberikan pada siswa. Tugas yang diberikan jangan terlalu berat. Bila memang kesulitan materi tidak dapat diturunkan guru harus menunjukkan perhatiannya pada siswa bahwa dia ingin mereka bisa sukses menyelesaikan materi tersebut.

\section{d. Membacakan cerita}

Cerita masih merupakan hal yang menarik bahkan bagi siswa SMA. Melalui cerita kita bisa mengkomunikasikan hal-hal yang rumit. Guru bisa memilih cerita atau buku yang didalamnya terdapat pesan moral yang sesuai untuk para siswa dan membacakannya secara periodik.

e. Aktivitas bermain peran

Role playing activity merupakan salah satu metode yang dapat meningkatkan pembangunan karakter siswa. Dengan 
memandang dari prespektif yang berbeda akan meningkatkan moralitas (Sofan Amri, 2011:100). Misalnya, siswa bisa diminta memberi pendapat tentang perasaannya seandainya dirinya menjadi salah satu pelaku sejarah dalam pelajaran sejarah. Hal ini bisa meningkatkan kemampuan empati para siswa.

f. Meningkatkan rasa tanggung jawab siswa Dengan meningkatkan rasa tanggungjawab siswa maka akan meningkatkan kerjasama dari pihak siswa (Bacon dalam Sofan Amri, 2011:100). Selanjutnya Djamarah, S.B dan Aswan Zain (2010:90) mengatakan bahwa: "Salah satu strategi dalam meningkatkan tanggung jawab siswa adalah dengan menugaskan siswa untuk mencatat apa saja yang telah dilakukannya di sekolah, apa saja prestasi yang dibuatnya dan kesalahan atau kegagalan apa yang dilakukannya”. Dengan melakukan hal ini, diharapkan dapat meningkatkan rasa tanggung jawab siswa. Catatan ini nantinya akan dikomentari atau diberi umpan balik oleh guru. Guru juga bisa memberikan goal setting pada para siswa. Guru menetapkan capaian yang akan dicapai bersama siswa dalam jangka waktu tertentu.

\section{KESIMPULAN}

Hasilnya, peran guru dalam pelaksanaan pendidikan karakter pada siswa sangat baik serta memberi dampak positif pada guru maupun siswa kelas X di Sekolah Menengah Atas 1 Negeri Palangka Raya.

Berdasarkan hasil penelitian dengan adanya komitmen guru dalam pelaksanaan pendidikan karakter sangat baik karaena mencapai $83,83 \%$ dan ini mengandung makna bahwa guru telah melaksanakan pendidikan karakter di sekolah berdasarkan komitmen yang disepakati bersama. Selain itu bentuk peran guru dalam pelaksanaan pendidikan karakter juga ada dalam katagori sangat baik, sebab mencapai $81,63 \%$ yang berarti peranan guru sebagai pendidik dilakukan dengan baik.

Sedangkan teknik yang digunakan guru dalam pelaksanaan pendidikan karakter juga ada dalam katagori sangat baik karena mencapai $86,19 \%$ yang berarti teknik yang digunakan guru dalam pelaksanaan pendidikan karakter dapat dilaksanakan dengan sangat baik.

\section{DAFTAR PUSTAKA}

Amri Sofan, dkk. (2011). Implementasi Pendidikan Karakter Dalam Pembelajaran (Strategi Analisis dan Pengembangan Karakter Siswa Dalam Proses Pembelajaran). Jakarta: Tim Prestasi Pustaka.

Asmani Jamal Ma'mur, (2011), Buku Panduan Internalisasi Pendidikan Karakter Di Sekolah,Yogyakarta: DIVA Press.

Baeley, D.K. (1982). Methods of Social Research, New York: A Devision of Mac Millan Publishing Co. Inc.

Baharuddin. (2007). Psikologi Pendidikan. Yogyakarta: Ar-Ruzz Media.

Djaali, (2006), Psikologi Pendidikan, Jakarta: PT. Bumi Aksara.

Djamarah, S.B., (2005), Guru dan Anak Didik Dalam Interaksi Edukatif, Jakarta: PT. Rineka Cipta.

Djamarah, S.B dan Aswan Zain. (2010). Strategi Belajar Mengajar. Jakarta: PT. Rineka Cipta.

Fatchul Mu'in, (2011), Pendidikan Karakter Konstruksi Teoritik dan Praktik, Yogyakarta: ArRuzz Media.

Gulo, Dali, (1982), Kamus Psikologi, Bandung: Tonis. 
Hadari Nawawi, (2003), Metode Penelitian Bidang Sosial, Edisi Revisi, Yogyakarta: Gajah Mada University Press.

Hadi, Sutrisno. (1993). Metodologi Research Jilid III. Yogyakarta: Andi Offset.

Hamid Darmadi, (2009), Kemampuan Dasar Mengajar (Landasan Konsep dan Implementasi), Bandung: Alfabeta.

Kartini, Kartono dan Gulo Dali. (1997). Kamus Psikologi. Bandung: Pionir Jaya.

Kertajaya, H., (2010), Grow With Character: The Model Marketing, Jakarta: PT. Gramedia Pusaka Utama.

Margono, (2005), Metodologi Penelitian Pendidikan, Jakarta: Diva Press.

Novan, A.W., (2012), Manajemen Pendidikan Karakter Konsep dan Implementasinya di Sekolah, Yogyakarta: PT. Pustaka Insan Madani.

Riduwan, (2004), Statistika Untuk Lembaga dan Instansi Pemerintahan/Swasta, Bandung: Alpabeta.

Sardiman AM, (2008), Interaksi dan Motivasi Belajar Mengajar, Jakarta: PT. Raja Grafindo Persada.

Suharsimi Arikunto, (2001), Prosedur Penelitian Suatu Pendekatan Praktis, Jakarta: Bina Aksara.

Undang-Undang Republik Indonesia No. 20 Tahun 2003, Tentang Sistem Pendidikan Nasional, Bandung: Citra Utama. 